\title{
O TEMA DO VOLFRÂMIO E O NEORREALISMO
}

\section{THE WOLFRAM TOPIC AND NEOREALISM}

\author{
Maria de Fátima Marinho
}

\section{RESUMO}

A importância da extração do volfrâmio durante a Segunda Guerra Mundial e as correspondentes consequências sociais e políticas terão, como seria de esperar, reflexos na literatura da época e na imediatamente posterior. A corrente neorrealista aproveitou-se deste fenómeno e dos problemas económicos e sociais que ele levantou e explorou-o em algumas das obras que podemos considerar paradigmáticas. Falamos dos contos Minério, de Miguel Torga (1941) e Ladrão!, de Marmelo e Silva (1943), bem como dos romances Volfrâmio (1943), de Aquilino Ribeiro e Minas de San Francisco (1946), de Fernando Namora. Apesar de não os poderemos considerar romances (ou contos) históricos, a verdade é que eles retratam as condições de vida das personagens e as mudanças que advieram das novas circunstâncias. Destacamos ainda um romance de 2008, de Miguel Miranda, intitulado $O$ Rei do Volfrâmio - A última viagem com todo o requinte. O tom irónico e caricatural da última obra nada tem a ver com a problemática séria e empenhada dos textos dos anos 40 . O contraste faz ressaltar a diferença entre o tratamento influenciado pela estética neorrealista e o aproveitamento sarcástico e de cariz alternativo da História em alguns dos romances contemporâneos.

PALAVRAS-CHAVE: neorrealismo; volfrâmio; romancehistórico; condições socioeconómicas.

\footnotetext{
1 Maria de Fátima Marinho leciona na Faculdade de Letras da Universidade do Porto desde 1976. É Professora Catedrática, foi Diretora da Faculdade de Letras (2010-2014) e também Vice-Reitora da Universidade do Porto, com o pelouro das relações externas e da cultura (2014-2018). É membro do Conselho de Administração da IAU (InternationalAssociationofUniversities), perita do Haut Conseil de l'Évaluation et de la Recherche de l'EnseignementSupérieur (França) e avaliadora externa das A3ES. A sua área de estudo é a poesia portuguesa do século XX e o romance histórico dos séculos XIX e XX. Fez conferências em inúmeros países e de entre as suas publicações salientam-se livros, capítulos de livros e artigos em revistas da especialidade.
}

\section{(c) BY-NC} A revista Metamorfoses utiliza uma Licença Creative Commons - Atribuição-NãoComercial 4.0 Internacional (CC-BY-NC).

Metamorfoses, Rio de Janeiro, vol. 16, número 1, p. 122-136, 2019 


\begin{abstract}
The importance of the extraction of the wolfram during World War II and the corresponding social and political consequences will have, as expected, reflections in the literature of the time and in the immediately subsequent one. The neorealist current took advantage of this phenomenon and the economic and social problems that it raised, and explored it in some paradigmatic works. We are talking about Minério, by Miguel Torga (1941) and Ladrão!, by Marmelo e Silva (1943), as well as the novels Volfrâmio (1943), by Aquilino Ribeiro and Minas de San Francisco (1946), by Fernando Namora. Although we cannot consider them historical novels, the truth is that they portray the living conditions of the characters and the changes that came from the new circumstances. We also highlight a novel (2008), by Miguel Miranda, O Rei do Volframio - A última viagem com todo o requinte. The ironic and caricatured tone of this last work is very different from the political and social commitment of the 1940s' texts. The contrast emphasizes the difference between the treatment influenced by the neorealist aesthetics and the sarcastic and alternative use of history in some of the contemporary novels.
\end{abstract}

KEYWORDS: Neorealism; wolfram; historical novel; social and economic conditions.

Quando, no início do século XIX, Walter Scott punha como subtítulo do seu primeiro romance, « 'tis sixty years since», estava, não só a marcar a distância temporal em relação ao tempo da escrita, como a significar a diferença entre o modo de escrever sobre o que se testemunhou e aquilo que apenas conhecemos pela leitura de textos ou de relatos indiretos. Avrom Fleishman, no seu clássico estudo sobre o romance histórico inglês, põe como condição a existência de pelo menos duas gerações entre a escrita do livro e o momento cronológico do enredo (FLEISHMAN, 1971, p.3), acrescentando que é tacitamente aceite a necessidade de haver referência a acontecimentos ou pessoas reais para criar uma certa credibilidade (FLEISHMAN, 1971, p.3). Esta definição, que se adapta ao romance histórico tradicional e que reflete uma conceção estática do passado, modificase, na medida em que se tendem a abandonar crenças rígidas e absolutas sobre os fenómenos que constituem o repositório da cultura e dos acontecimentos que marcaram determinada época histórica.

A discussão sobre a necessidade de manter a distância de duas ou três gerações, como queriam os românticos, está longe de ser consensual. Se, por um lado, a necessidade de distinguir entre a transcrição do acontecimento apreendido através de textos seus coetâneos, mas irremediavelmente afastados do romancista que os recria, e a reprodução escrita de factos diretamente vivenciados pelo autor, se pode revelar operativa, por outro, não é menos verdade que o real é sempre algo de fugidio e renitente ao tratamento romanesco. Aquilino Ribeiro estava ciente dessa dificuldade inultrapassável quando, no prefácio à segunda edição de Volfrâmio, datado de fevereiro de 1944, escreve que "o orgulho do criador estará em dar a ilusão de que são cópias exactas do mundo de carne e osso"(RIBEIRO, 1961, p. 8), afirmando mais adiante que a sua escrita se rege por dois princípios complementares: "observância do real e originalidade"(RIBEIRO 1961, p. 11).

A crença de que a literatura poderá ser simultaneamente a ilusão da representação do real e a sua construção mais privilegiada, tem feito correr rios de tinta e não poderá ser resolvida 
de modo simplista e apressado. Sabemos que a consciência de que a arte da narrativa sempre contribuiu para a invenção de novos tempos (HAMEL, 2006, p.7) consolida-se na representação do irrepresentável (FOREST, 2007, p. 45), isto é, na tentativa de conciliar o real (fugidio, inexistente sem a construção que dele é feita) e a sua representação, que sempre se transforma em modos mais ou menos conscientes de manipulação (LIMA, 2006, p. 147). A crença de que a ficção pode ser documentada e reproduzir determinados momentos históricos, como queria Barbara Foley (1986), está longe de poder ser aceite, sem previamente se assumir o estatuto de ingenuidade, impróprio de um leitor avisado, que sabe não poder comungar de tal postulado (LIMA, 2006, p. 152), sob pena de incorrer na armadilha que o historiador a si próprio cria quando se quer distanciar irremediavelmente do romancista. O referente histórico é assim sempre construído (BOUJU, 2006, p. 111), tendendo a legitimar, de forma mais ou menos consciente, a ideologia, o interesse e as opções de quem escreve (LIMA, 2006, p. 156).

Toda a ficção pressupõe um documento escondido, subjacente, como toda a História tem sempre o seu quinhão de ficção, de construção, de invenção. Aceitando este princípio estético, não será difícil conciliar as duas realidades, mesmo se com propósitos ou procedimentos diferentes (BARONI, 2007, p. 266).

A discussão sobre a distância temporal necessária para considerar um texto como fazendo parte do subgénero do romance histórico poder-nos-ia levar para variados domínios, todos eles bastante ociosos ou inúteis. $\mathrm{Na}$ verdade, o conceito que subjaz à designação implica, talvez, o trabalho sobre realidades que tiveram lugar numa época anterior cujo conhecimento só chegou indiretamente, através de documentos, sejam eles de que natureza forem. A escrita pretensamente objetiva sobre o passado infere obrigatoriamente de inverdades involuntárias e nem sempre catalogáveis. A certeza de que só se conhece uma ínfima parcela da totalidade, que constitui a realidade de outras eras, legitima o aparecimento de romances que jogam com a ignorância absoluta de certos domínios ou de certas opiniões, e, por conseguinte, realçam os interstícios, os segredos, os marginais (pobres, mulheres, grupos pertencentes a minorias, étnicas, religiosas ou outras) da História, chegando ao ponto de modificar o passado, na mira de problematizar um conhecimento de cuja fidelidade os autores se permitem duvidar. Perante estas afirmações, pareceria, à primeira vista, que os textos, que se debruçam sobre realidades coetâneas dos romancistas, não infeririam dos mesmos problemas ou das mesmas limitações. No entanto, como diz Manoel de Oliveira, ao comparar o cinema e a literatura,

Na literatura, o documentário não existe. Antes havia os cronistas, as crónicas, as narrativas dos descobrimentos...Eram histórias que contavam as coisas que se passavam. Mas era o cronista que contava aquilo que ele pensava e via. Não era a própria realidade que transparecia, ou que tendia a transparecer, mas já havia uma forte interpretação pessoal. (...) O cinema-verdade não é nada verdade, era uma grande mentira, porque as pessoas, ao representarem, deturpam tudo o que se tinha passado, ocultam o que eles querem que não se saiba e exageram aquilo que mais desejam e lhes agrada. (BESSA-LUÍS e OLIVEIRA, 2007, p. 51). 
Por isso, Agustina diz: “(...) porque eu me sirvo da realidade, mas não confio nessa realidade, nem na dos cronistas" (BESSA-LUÍS e OLIVEIRA, 2007, p.52). E a desconfiança, paradoxalmente, provoca a construção de possíveis, isto é, o recurso a processos de representação que modificam o passado e o real ou os significam através de subtis entrelaçamentos, que impedem a catalogação rígida, mesmo se em alternativa, de história romanceada ou ficção documentada (BOUJU, 2006, p. 111).

Durante a Segunda Guerra Mundial, Portugal, com minas de volfrâmio, viu-se repentinamente no centro de um jogo de interesses, que favoreceram a extracção vertiginosa e, por vezes, selvagem e precipitada do minério. Logo nos anos 40, surgiram dois romances e alguns contos que se aproveitaram desta realidade para a atualizarem em matéria romanesca. Dum ponto de vista estrito, estes textos não poderão ser considerados como ficção histórica, dado que não se referem nunca ao passado, antes funcionam como uma espécie de documento ficcionado do presente, como é característica da ficção neorrealista.

As personagens atualizam os modos de relacionamento e os valores de um determinado momento histórico, tal como fez Lídia Jorge, em O Jardim sem Limites (1995) ou Combateremos a Sombra (2007).

Contudo, sabemos que toda a ficção pressupõe um documento escondido, subjacente, como toda a História tem sempre o seu quinhão de ficção, de construção, de invenção. Daí, não será, talvez, abusivo, estudar os textos produzidos na década de 40 e que versam o tema do volfrâmio, como documentos de uma determinada realidade, mas que a ultrapassam ou a modalizam, isto é, que, se partem de fenómenos extratextuais, os transformam, inequivocamente, em matéria literária. Sendo assim, a diferença entre o que comummente se designa de romance histórico e o romance que versa temas da atualidade não será muita, do momento em que se toma consciência de que o mais importante é perceber o modo como o discurso da História (passada ou recente, pouco importa) se mistura com o da ficção, implicando-se reciprocamente.

Partindo deste princípio, abordaremos quatro textos (dois contos e dois romances) dos anos 40 e um romance recente, de 2008, que se preocupam em estabelecer, de modos, curiosamente, muito idênticos, as circunstâncias da exploração do volfrâmio.

Começaremos por um pequeno conto de Miguel Torga, intitulado «Minério», incluído em Montanha, e, mais tarde, retirado pelo autor de todas as subsequentes edições. Este conto, até pelo ano da sua publicação, 1941, funciona como uma espécie de súmula dos textos mais longos que só vieram a lume uns anos depois. Começando por descrever uma natureza idílica e repleta de habitantes eivados dos saberes tradicionais autênticos, acaba por mostrar a riqueza fácil advinda da exploração do volfrâmio, a corrupção e inevitável pobreza. Esta sequência poderia ser aplicada a todos os textos que se debruçam sobre este problema e apresentam desenvolvimentos mais ou menos idênticos. Vejamos o início do conto, que apela ao tópico do locus amoenus e da perfeição utópica: "Dantes, a montanha era pacífica e farta. Dava pão, 
vinho, castanhas e lã.'(TORGA, 1941, p.171). Este equilíbrio é quebrado pela descoberta, primeiro ainda incipiente, mas depois, efetiva do minério:

Mas se os homens da montanha esqueceram as maluquices do senhor Vasco, os homens das terras baixas guardaram na memória atenta a lembrança das pesquisas que fez. E eis novamente a montanha visitada pela cobiça do minério. Mas dantes o senhor Vasco abria pequenas covas de sete palmos, como se fossem para sepultar apenas o seu sonho; agora os homens que vieram começaram a abrir poços sem fundo.

A montanha, mesmo assim, não quis acreditar. Pão, vinho, castanhas e lã. Nunca daquelas fragas tinha saído mais. Mas o Manco, o pastor, achou um seixo muito pesado, com laivos negros. Foi vendê-lo ao senhor Williams. Quarenta e cinco mil réis! Alto! Os fraguedos, afinal, valiam. E a montanha deixou de dar pão, vinho, castanhas e lã, para dar minério. (TORGA, 1941, p. 173).

A riqueza fácil e inusitada marca o fim da ingenuidade e a transformação de hábitos e mentalidades. A própria menção ao patrão inglês (Williams) revela a mudança e legitima a corrupção e o roubo encapotado. A prevalência do estrangeiro atenua, de certa forma, a culpa, facilitando atividades que cada um reprovaria, mas que a montanha, visionada como um todo indiferenciado, leva a cabo sem remorsos:

E soubera que pelos modos lá para os lados de Viseu andava também assim uma grande exploração de mineral. Mas pagavam-no por bom preço...Vinte mil réis...Era só ir lá entregá-lo...

A montanha ouviu a novidade e coçou a cabeça. Vinte mil réis... Mas então...

E foi assim que a montanha se perdeu. Não é que não seja justo roubar o senhor Williams. É. Mas que pena a montanha ter de aprender a roubar! De certeza. Não fosse o senhor Vasco começar e depois o senhor Williams continuar, ninguém na montanha se lembraria de fazer contrabando. De certeza. (TORGA, 1941, p. 176).

A conclusão é deprimente, “A pobreza da montanha nem assim deixa de ser maior dia a dia"(TORGA, 1941, p. 178), o estrangeiro vai enriquecendo e os locais morrem e são mortos: "Por outro lado, o senhor Williams, à medida que a serra vai dando menos, reforça a vigilância do contrabando. E só numa noite a guarda matou três na Garganta.” (TORGA, 1941, p. 178).

A disforia presente no fim do conto contrapõe-se à euforia do início, a utopia deu lugar à crua realidade e à exploração fria e calculista.

Depois da publicação deste pequeno conto, sucedem-se, na mesma década, um conto de José Marmelo e Silva, "Ladrão!" (o título na 1'edição é “O Conto de João Baião"; o título definitivo só aparece na $2^{\mathrm{a} e d i c ̧ a ̃ o, ~ d e ~ 1965), ~ i n c l u i ́ d o ~ n a ~ c o l e c t a ̂ n e a ~ O ~ S o n h o ~ e ~ a ~ A v e n t u r a ~(1943), ~}$ Volfrâmio (1943), de Aquilino Ribeiro e Minas de San Francisco (1946), de Fernando Namora.

Marmelo e Silva refere ainda o trabalho nas minas, de passagem, no romance Adolescente Agrilhoado (1948). O facto de o narrador colocar o pai de família a trabalhar nas minas demonstra, 
de forma liminar, a importância que esse trabalho assumiu num determinado momento histórico e as condicionantes que proporcionou:

Cansado da mesquinhez das terras arrendadas, o pai trabalhava agora na mina de volfrâmio dos ingleses como carpinteiro-escorador. Só vinha a casa ao sábado, e sempre à frente de uma grande fila de mineiros. ("Não que ele eram muitas léguas, tudo por caminhos ruins!") - já tinha dito à mãe. (MARMELO E SILVA, 2002, p. 281).

Aliás, Luís Miguel, no fim do romance, desalentado e desesperado, decide ensinar os mineiros ("Vou instruir um grupo de mineiros.", MARMELO E SILVA, 2002, p. 382), num aceno de esperança. Apesar de se tratar de uma referência ténue, a verdade é que ela é devedora de uma realidade característica de uma determinada época e de um grupo social definido.

Será, no entanto, nos outros textos citados que veremos o desenvolvimento das coordenadas que Torga já enunciara no pequeno conto a que fizemos referência. Além das inevitáveis diferenças entre os três, que decorrem sobretudo de pormenores da intriga, menos relevantes para o estudo que nos interessa, detetámos seis pontos que se repetem e que poderão constituir uma espécie de paradigma dos romances do volfrâmio, ou antes, dos elementos que apontam para a deteção do real, mesmo se transposto e modificado pela escrita. É essa apreensão de um suposto real que poderá aproximar a escrita destes textos do romance histórico, apesar das divergências inequívocas que decorrem da atualização de algo que não foi possível testemunhar, dada a distância temporal que separa os dois momentos fulcrais (o facto e a sua reescrita) ou de algo que se está a passar no momento em que se está a proceder à efabulação. As seis coordenadas fundamentais que se encontram na construção dos romances são as seguintes: utopia, mudança de valores, desestruturação da família, paradigmas familiares e sociais, más condições de trabalho, corrupção.

A utopia marca a euforia inicial, fruto da quebra do equilíbrio "a euforia glutónica do volfrâmio"(MARMELO E SILVA, 2002, p. 252), como diz o narrador de “Ladrão!”, de José Marmelo e Silva. E acrescenta que:

Os farrapilhas lá da terra, que nunca vestiram uma camisa que não fosse rechapada ou por esmola, exibiam roupas femininas, caras, exóticas, lavavamse em cerveja, fumavam tabaco embrulhado em notas de cem escudos. Quantas loucuras para se mostrarem gente, enfim! (MARMELO E SILVA, 2002, p. 253).

Aquilino Ribeiro, no prefácio já citado, escreve que:

O volfrâmio foi para as populações do Norte, deserdadas de Deus, o que o maná foi para os Israelitas através do deserto faraónico. Imagine-se o que seriam os impulsos da horda esfaimada ante o alimento providencial, no afogo do dejejum. $\mathrm{O}$ irmão engalfinhar-se-ia com o irmão. $\mathrm{O}$ mais forte encheria duas vezes $\mathrm{o}$ saco, enquanto o mais débil choraria lágrimas de sangue, dado que não ficasse britado pelos pés dos digladiadores. Levaria melhor, se não o mais violento, $\mathrm{o}$ mais astucioso e o que tivesse olho rápido e pé leve. (RIBEIRO, 1961, p. 8). 
É a verdade que transparece no conto de Marmelo e Silva e em todo o romance de Aquilino, onde as personagens se digladiam por uma riqueza de que ainda nem têm bem consciência:

Que levava ali? Ao certo não saberia responder, se lho perguntassem. Levava pedras, à conta bem feita. Algumas deviam ser de volfrâmio e de volfrâmio puro, a avaliar pelo peso e pelo brilho com que acenavam aos olhos suas faces espelhadias; outras encerravam para ele um mistério com as palhetas resplandescentes, os grânulos de oiro e verde-salsa incrustados em granito, quando não eram concretos opacos e ferruginosos como torresmos de forja. (RIBEIRO, 1961, p. 58-59).

A mesma loucura se nota em Minas de San Francisco, onde a construção do lugar se estrutura em torno da nova realidade:

Com os ventos de Espanha, corria agora a notícia de um achado de oiro negro, escondido nas rochas, saltando dos rasgões das enxadas, que enriquecia os farroupilhas de um dia para o outro. Eram pedras que rendiam oiro, lá onde apareciam estrangeiros que compravam terrenos áridos e os furavam como toupeiras, empreitando camponeses, pagando jornas de loucura. (NAMORA, 2003, p. 14);

Volfrâmio! Um berro de loucura, uma enxurrada de risos, ódios, febres, rompendo comportas milenárias. As aldeias tinham uma alegria nova; o vinho corria nas gargantas ávidas, o comércio prosperava. (NAMORA, 2003, p. 34).

Este discurso, aparentemente, pleno de índices positivos, revestir-se-á de grande negatividade à medida que a utopia inicial se vai desfazendo e se vão revelando as verdadeiras consequências da exploração desenfreada: "Oh, maldito ele fosse! Matara-lhe o Duarte e não havia dúvida que fora ele quem assassinara o José Francisco à traição. Procurassem bem e não culpassem outro. Fora o volfro, o barzabu negro e malvado!"(RIBEIRO, 1961, p. 371).

A mudança de valores, visível na última página de Volfrâmio, "Milhares de milhares de gajos análogos a atirar bombas ou ideias, e o mundo continuava a rolar como dantes. Quem o governava, corpos e almas, era o dinheiro.”(RIBEIRO, 196, p. 457), é subtilmente insinuada em toda a trama de Minas de San Francisco, desde o desengano que António sofre quando percebe que a amante, prostituta, que tantos presentes e dinheiro dele recebeu, lhe recusa ajuda num momento de aflição, até ao desabafo de João Simão, o homem destruído, física e espiritualmente, pelo fenómeno do volfrâmio: "Um homem, em chegando a San Francisco, vende a alma ao diabo. Já não sabe mais onde o negócio vai parar e o que levará de si próprio à saída. Eu vendi os meus olhos e outras coisas que talvez vocês todos já tenham perdido também.” (NAMORA, 2003, p. 199).

São as outras coisas a que se refere João Simão, simbolizadas na desonra e gravidez da filha, apaixonada por um engenheiro das minas, Almeida, que poderão significar a desestruturação da família de que falávamos há pouco. O mineiro abandona a família e recolhe-se a um lar, desesperado pela impotência que sente perante a filha; o pai de António embrenha-se numa 
mina, simbolizando um suicídio, na recusa completa dos esquemas do filho e das radicais mudanças que se fizeram sentir. Em "Ladrão!", os dois irmãos, desavindos, pensam no lucro proveniente do volfrâmio. No romance de Aquilino, o adultério assume-se como um símbolo da mudança de valores, que desaguam na anulação do conceito tradicional de família.

Esta mudança é corroborada pelo aparecimento de quatro pares paradigmáticos, que significam realidades diferentes, mas todas elas pertencentes ao universo referencial em apreço: dois irmãos solteiros, remoendo traumas e ambições; um engenheiro e uma rapariga seduzida; dois engenheiros de diferentes sentimentos; ingleses e alemães em confronto.

Os irmãos, Bárbara e Duarte, de Volfrâmio, vivem uma ambígua relação, onde sobressai a inteligência e desembaraço da irmã, antiga apaixonada de um homem, a quem se entrega no final, deixando-lhe, ao morrer, a herança; o desespero de Duarte é mais flagrante, na medida em que se suicida, depois de perceber o roubo de que foi alvo. Destruídos por um ambiente onde reina a cobiça e a hipocrisia, os irmãos representam tipos, que se podem considerar representativos de um momento histórico determinado.

O mesmo se passa em relação ao par constituído pelo Engenheiro Almeida e por Maria do Freixo, filha de João Simão, personagens do romance Minas de San Francisco. Maria encarna a típica rapariga ingénua, seduzida e crente no amor do engenheiro; este, por sua vez, "Tem de reconhecer que cada um dos seus gestos é deliberado, fios de uma teia onde ele sabe que a presa está aprisionada. É inútil mascarar a intenção." (NAMORA, 2003, p. 104); "Quebrada a violência do desejo, sentia-se mais lúcido para valorizar os seus sentimentos e as pequenas e grandes coisas que os uniam e desuniam, reconhecendo a fragilidade daquela ligação." (NAMORA, 2003, p. 142).

Tal como diz o Engenheiro Garcia, Almeida deve defender-se porque "Foi a mina que o transtornou. Defenda-se da mina, Almeida!” (NAMORA, 2003, p. 239).

O epílogo feliz e cheio de esperança vem mais uma vez pôr a tónica no sentido messiânico que, apesar de tudo, ainda parece estar no fim dos romances: "Apenas sabe que ele virá um dia, de San Francisco ou dos mares de neblina, para fazer dela sua mulher.'(NAMORA, 2003, p. 266).

A falta de originalidade da situação descrita ultrapassa o enredo particular de Fernando Namora para se constituir paradigma de relações estereotipadas, como é o caso da descrição que é feita dos dois engenheiros, personagens que encarnam as diversas sensibilidades ou os diversos modos de lidar com os trabalhadores das minas:

Almeida fica desorientado. Aquela é precisamente a humilhação que ele não previa e que ofende mais do que qualquer outra. Sente-se pueril, insignificante, à mercê desse homem que sabe o que quer, senhor dos seus méritos e dos seus erros. Esse Garcia é o único digno de San Francisco. (NAMORA, 2003, p. 202), 
pois se mantém distante dos trabalhadores, não se envolvendo emocionalmente numa relação considerada impossível e condenada ao fracasso.

Em Volfrâmio, há ainda a dupla ingleses/alemães cuja funcionalidade é a de fazer ressaltar a ambiguidade dos interesses em jogo, que refletem a ambiguidade de posições do governo português da época.

Destes paradigmas sociais e culturais, bem característicos da estética neorrealista que pretendia denunciar a exploração das classes trabalhadoras, facilmente passaremos para uma outra constante dos dois romances ou seja, a representação das más condições de trabalho a que estavam sujeitos os mineiros e a correspondente corrupção.

A reiteração dessas más condições destina-se a salientar o fosso que se vai criando entre os que enriquecem facilmente e os que se deixam envolver por um mundo que os destrói:

Aos dois homens, tirados debaixo dos escombros depois de porfiosa labuta, é que não houve santo nem santa que valesse. Lá foram para a terra da verdade, deixando mulher e filhos que no dia seguinte se viam pelas leiras, mais dobrados para o chão, mais testos dos sentidos, ao rebusco de volfro com que pagar o enterro.

$\mathrm{O}$ desastre fora previsto. Homem de entendimento claro, mas de todo ignorante, o Calhorra propunha-se obter o máximo resultado com o mínimo de dispêndio, e toca "a dar-lhe para a frente". A entivagem era a mais precária que se pode imaginar. (RIBEIRO, 1961, p. 289).

O máximo cinismo parece estar na frase a seguir transcrita, retirada do romance de Fernando Namora: "E o relatório final que o sindicato leva para Lisboa conclui que o acidente foi obra de um horroroso descuido do mineiro. A Companhia não é responsável.’(NAMORA, 2003, p. 243).

De igual modo, a corrupção, frequentemente atualizada no contrabando, percorre os universos romanescos, desde a repetição exaustiva da necessidade de revistar os trabalhadores, que tentavam roubar o volfrâmio para o venderem por conta própria, até às várias manobras que se fazem para tentar tirar o máximo proveito da riqueza efémera:

Garcia sorria. Conhecia a léria. Todos os negociantes ali vinham fornecer géneros madeiras, carvão, roubavam com uma desfaçatez irritante. Enojavam. Apetecia-lhe às vezes expulsá-los dali a cavalo-marinho. Humilhava-o perceber que esses labregos supunham ludibriá-lo, mas como essas questões de economia doméstica o enfadavam, deixava correr, sorrindo, tornando-se cúmplice com a sua orgulhosa complacência. (NAMORA, 2003, p. 125);

Tem a certeza de que é simplesmente um ladrão da Companhia, que a mina é uma capa para os seus negócios tortuosos e colossais. (NAMORA, 2003, p. 132);

Os três sócios requintavam em roubar-se reciprocamente com tão seguro jeito e malignidade que, lançados os latrocínios numa balança de ourives, chegar-se-ia a concluir que cada um deles tinha exatissimamente sacado o seu quinhão. (RIBEIRO, 1961, p. 345). 
Em Volfrâmio chega mesmo a referir-se que, frequentemente, se tentam enganar os estrangeiros:

\footnotetext{
À boca cheia se contava que impingia a mister Corbet gato por lebre. Os sacos que ele tareava e pesava iriam atestados de titânio e da mais ignóbil morraça com uma película de volfrâmio à superfície para o conspecto inicial, e seria este o primeiro passe do manigante. (RIBEIRO, 1961, p. 263).
}

Devedores da estética neorrealista, mesmo se de forma nem sempre completamente ortodoxa, os textos analisados comungam de um postulado idêntico, que os aproxima.

Apesar de versarem um tema que é facilmente referenciável no discurso da História, a verdade é que a ausência de distância temporal impede a catalogação tradicional, embora se possa considerar que estamos em presença de um documento cuja representatividade pode ser legitimadora de uma época.

O verdadeiro romance histórico, porém, será o de Miguel Miranda, O Rei do Volfrâmio A última viagem com todo o requinte (2008).

Neste romance, o narrador assume a reconstrução inevitável a toda a evocação histórica, afirmando primeiro que "Recei[a] estar a reconstruir um passado falso(...)" (MIRANDA, 2008, p. 12) e que “(...) havia uma espécie de medo, um absurdo receio de [s]e confrontar com o passado, descobrir que ele não existira, ou quebrar uma boa memória com a descoberta de uma má realidade.”(MIRANDA, 2008, p. 12). É este o jogo constante que o narrador nos propõe, mudando constantemente a focalização e a pessoa narrativa. $\mathrm{O}$ artifício, que consiste em alternar a voz, favorece o aparecimento do enigma e de um certo suspense, nem sempre muito bem conseguido. Estamos, fundamentalmente, em presença de dois tempos, que se completam e se desvendam reciprocamente. O narrador homodiegético, professor a preparar uma tese de doutoramento sobre o fenómeno do volfrâmio, confronta-se com um passado que não consegue resolver e que, afinal, é mais falso do que seria previsível. Toda a efabulação parece apontar numa direcção que se revelará completamente equívoca.

Genericamente, poderemos dizer que o romance repete os mesmos temas e paradigmas dos anteriores, publicados cerca de sessenta anos antes, contemporâneos da realidade a que fazem referência. A diferença reside no emprego das diferentes focalizações que correspondem a épocas diversas ou a meios distintos e, por vezes, antagónicos. Cabe ao leitor o confronto entre as informações fragmentadas, nem sempre bem conectadas, construindo a totalidade, decetiva e desconcertante.

Há, assim, vários níveis narrativos para lidar com o passado, interceptando-o com o presente, desinteressante, confuso e gerador de angústia permanente. O passado, pelo contrário, apresenta-se mais linear, factual, com focalização predominantemente externa. Dos anos 40, 
sobressaem as figuras do pai do narrador, que assume, pontualmente, a primeira pessoa, a de Petrónio Chibante, volframista, da rapariga que ele seduziu e abandonou, Serafina Amásio, do Cônsul português em Bordéus, Aristides Sousa Mendes, do Chacal, revolucionário basco, de uma mulher, de identidade duvidosa, paradigma da espia da segunda guerra, e, finalmente, de trabalhadores mais ou menos indiferenciados, que se destinam a compor um quadro verosímil, embora subtilmente caricaturado, se tivermos em conta as descrições de Aquilino Ribeiro ou Fernando Namora.

O pai do narrador, chamemos-lhe principal, engenheiro de minas, funciona como o aparente ponto de contacto entre os dois tempos. É o engenheiro frio, técnico, cujas relações com o pessoal trabalhador ignoramos em absoluto (ao contrário do que acontecia com os Engenheiros Garcia e Almeida, de Minas de San Francisco), até por que, para a economia narrativa, só interessa a sua profissão, enquanto pai de uma personagem que trabalhará a importância do volfrâmio num determinado momento histórico:

O meu pai, explicando a aplicação do volfrâmio nas ligas de ferro para conseguir maior dureza, a sua importância na indústria de guerra, no fabrico de armas e munições. (...) A minha tese, que nunca mais desencalhava. Rubina, limpando nódoas invisíveis dos vidros. Joana, espalhada na cama depois de uma noite de sexo furibundo. Stella, ainda ausente. Eu, assistindo à minha vida, sentado a uma mesa do café Guarani, com um empregado de casaca branca levitando em círculos. (MIRANDA, 2008, pp. 43-44).

A citação transcrita define o ambiente do presente e a personagem que o protagoniza: confinado entre um pai, frio e profissional, uma esposa (Rubina), desinteressante e frívola, e duas amantes que se completam, o narrador tem dificuldade em investigar um assunto e redigir um trabalho sobre algo que sente escapar-lhe irremediavelmente. E a verdade é que o logro se instala e a relação que ele pensa ter com o mundo do volfrâmio (neto falso de um antigo volframista, Petrónio Chibante) é apenas a do pai, distante e impessoal.

O volframista encarna uma espécie de paradigma do industrial bem sucedido, sem princípios ou valores estabelecidos. Liga-se, por cálculo, quer aos interesses do governo português da época (ditatorial e próximo do fascismo), quer a um revolucionário basco, que lhe impõe uma arriscada missão, que envolve falsificação de documentos e transporte de uma mulher enigmática, por quem ele se vem a apaixonar e que aproveita esta paixão para o roubar e enganar.

O cônsul em Bordéus, figura bem conhecida da História portuguesa, funciona sobretudo pelo conhecimento implícito que dele poderá ter o leitor, não havendo nunca alusões muito detalhadas ao seu papel na evasão dos judeus perseguidos. As referências que lhe são feitas limitam-se quase a evocá-lo na pressuposição de um conhecimento inequívoco: 
O volframista apresentou-se:

- Sou Petrónio Chibante. Volframista de Vilar das Almas, uma terra do Norte. Vendo minério para Espanha. Também para França e Alemanha.

O diplomata olhou para ele surpreso. Estava longe de cruzar com o Rei do Volfrâmio, em pessoa. Só o conhecia de documentos secretos do consulado. Sorriu e anunciou-se:

- E eu sou Aristides de Sousa Mendes. Cônsul-geral de Bordéus. (MIRANDA, 2008, p. 176).

As alusões ao cônsul são regra geral esporádicas e só ganham alguma importância quando referem o seu dilema entre a vontade de salvar os judeus e as ordens terminantes de Lisboa ou o momento da sua destituição:

- Há milhares de refugiados. Judeus, que fogem da morte. Perseguidos pelos alemães. Só podem atravessar Espanha com um visto meu, dizendo que vão em trânsito para Portugal. Chegaram ordens do governo, a proibir-me. Apiedei-me dos primeiros e passei meia dúzia de vistos. Começaram a chover pedidos. Algumas centenas. Pedi instruções superiores e proibiram-me outra vez. Agora, já são aos milhares, são vozes lancinantes que carrego dentro de mim. (MIRANDA, 2008, p. 229);

- O senhor cônsul não voltará. Foi destituído. (MIRANDA, 2008, p.246).

Apesar destas incursões entre passado e presente, não há nunca uma real interferência entre os dois tempos que estão, à partida, bem diferenciados, não havendo audácias narrativas ou problematização das relações entre duas épocas ou personagens que se definem reciprocamente, como encontramos em Agustina Bessa-Luís ou Hélder Macedo.

A forma narrativa ainda é bastante a tradicional e não faltam no romance os elementos que destacámos nos textos da década de 40: utopia, mudança de valores, desestruturação da família, figuras paradigmáticas e corrupção. As condições de trabalho nunca são referidas, ao contrário do que acontecia nos romances coevos da exploração do minério, parecendo não interessar minimamente para o enredo.

O primeiro momento é de euforia e de grande esperança:

Como o resto do país, Vilar das Almas foi bafejada pela sorte, quando a máquina de guerra alemã se pôs em movimento. (...) O couto mineiro do Paraíso deu emprego a muita gente da aldeia e redondezas, tendo chegado, nos tempos áureos da sua exploração, a empregar mais de um cento de almas. (MIRANDA, 2008, p. 71).

A riqueza fácil legitima a mudança de valores, que se notam na ausência de escrúpulos e na desestruturação da família tradicional, simbolizada na atracção de Chibante pela aventureira e no correspondente abandono de Serafina. Aliás, esta rapariga, oportunamente afastada pela família, para fazer esquecer a vergonha, aparece, no presente, octogenária e morta, em França, 
sendo carregada, pelos sobrinhos-netos, no carro, para evitar o dispendioso transporte funerário. Esta viagem do casal com a morta tem características que a aproximam da comédia e funciona ironicamente em relação ao título do romance.

Quer os sobrinhos-netos da morta, emigrantes em França, quer o volframista, o revolucionário e a espia, que engana Chibante, são paradigmas de tipos sociais da época.

A corrupção é uma constante, visível em diversos pormenores, que vão desde os negócios paralelos até à falsificação de documentos, à espionagem de vários sinais, à riqueza fácil e à ausência de princípios, morais ou outros.

A intriga, que lembra, por vezes, a dos romances de aventuras, assenta num logro, logro este que destrói a pretensa veracidade do narrado. Depois de buscas infrutíferas do narrador na casa que fora de seu pai e, antes disso, de Petrónio Chibante, o protagonista descobre uma fotografia e cartas que parecem desvendar o passado. De igual modo, o narrador heterodiegético mostra conhecer a verdade que é desconhecida das personagens, dada a ignorância total do passado e o juízo fundado nas aparências. A passagem que fala de um livro valioso, que o leitor sabe ser falso, lembra o fim do romance El Sueño de Venecia de Paloma Díaz-Mas, onde a explicação que é fornecida de um quadro é totalmente errada, embora só o leitor disso tenha conhecimento:

Seria impossível a João António Linhares Curvaceira Gaioso Diógenes de Deus [o narrador homodiegético] saber que o Atlas Miller exibido na conferência, guardado com todas as medidas de segurança na Biblioteca Nacional francesa, mais não era que uma perfeita imitação, elaborada por volta de mil novecentos e quarenta e sete pelo falsário Foucault Dufresne. Não lhe seria também possível adivinhar que o original tinha sido transportado pelo volframista Petrónio Chibante, de Paris para o Porto, por este entregue no alfarrabista Chaminé da Mota, para seguir um percurso obscuro. Os tempos, os lugares, os factos roçavam-se sem se tocar. (MIRANDA, 2008, p. 271).

Este pequeno episódio prepara, numa espécie de estrutura em abismo, o embuste maior, isto é, a paixão, doença e morte da espia, que, combinada com Chacal, o revolucionário, se apodera do dinheiro do volframista:

Ima Brunhild recordou a farsa, com um sorriso. Engendrara o plano, quando se curara da tísica no Sanatório Rodrigues Semide. Comprara a colaboração dos médicos, o tisiologista Ramalho de Almeida e o professor Leonard. (...) Aos poucos tinha-lhe ficado com toda a fortuna. O último golpe fora a questão da filha. Que não era dele, mas do Chacal. (...)

Abraçou uma última vez o Chacal. Procurou-lhe os lábios, encontrou-o tenso e distante, como sempre. Ele não beijava tão bem como o volframista, mas tinha a mesma causa política do que ela. (MIRANDA 2008, pp. 277-278).

Mais do que um romance que pretende documentar a exploração do volfrâmio e suas consequências para a sociedade portuguesa, este livro de Miguel Miranda apresenta-se com um 
entrecho entre o divertido, o caricatural, o policial e o vagamente histórico. O passado tem uma funcionalidade pouco acentuada, servindo essencialmente de pretexto para a caracterização do narrador-protagonista, perdido e angustiado por um trabalho que não o realiza.

Concluindo, poderíamos dizer que a ficcionalização do fenómeno do volfrâmio é um modo de a narrativa se conciliar com o real, fugidio, enganador e, no fundo, inexistente. É impossível aceder ao passado ou mesmo a todas as circunstâncias de um presente complexo e contraditório. Só se consegue exprimir a ideia do real ou do que ele representa num determinado momento, não se pode reduplicá-lo, presentificá-lo ou mostrá-lo na sua totalidade. Nós sabemos que toda a ficção pressupõe um documento escondido, subjacente, como toda a História tem sempre o seu quinhão de ficção, de construção, de invenção: "Sabeis todos que, no fundo, não há cavalo que se pareça comigo ponto por ponto: eu sou apenas a Ideia do Cavalo que o pintor imagina. (...) Os verdadeiros cavalos diferem entre eles, e os verdadeiros pintores deverão ter isso em consideração..."(PAMUK, 2007, p. 251).

\section{Referências:}

BARONI, Raphaël. Histoires Vécues, Fictions, Récits Factuels. Poétique nº151, 2007.

BESSA-LUÍS, Agustina, OLIVEIRA, Manoel de. Um Concerto em Tom de Conversa. org. e intr. de Aniello Angelo Avella. Belo Horizonte: Editora UFMG, 2007.

BOUJU, Emmanuel. La Transcription de l'Histoire - Essai sur le Roman Européen de la Fin du XXe siècle. Rennes : Presses Universitaires de Rennes, 2006.

FLEISHMAN, Avrom. The English Historical Novel - Walter Scott to Virginia Woolf. Baltimore and London: The Johns Hopkins Press, 1971.

FOLEY, Barbara. Telling the Truth - The Theory and Practice of Documentary Fiction. Ithaca and London: Cornell University Press, 1986.

FOREST, Philippe. Le Roman, le Réel et Autres Essais. Nantes : Ed. Cécile Defaut, 2007.

HAMEL, Jean-François. Revenances de l'Histoire - Répétition, Narrativité, Modernité. Paris : Les Editions de Minuit, 2006.

LIMA, Luiz Costa. História. Ficção. Literatura. São Paulo: Companhia das Letras, 2006.

MARMELO E SILVA, José. Obra Completa, coordenação e prefácio de Maria de Fátima Marinho. Porto: Campo das Letras, 2002.

MIRANDA, Miguel. O Rei do Volfrâmio - A Última Viagem com todo o Requinte. Lisboa: Dom Quixote, 2008. 
NAMORA, Fernando. Minas de San Francisco. Lisboa: Publicações Europa-América, 2003 [1946].

PAMUK, Orhan. O Meu Nome é Vermelho, tradução portuguesa de Filipe Guerra. Lisboa: Presença, 2007 [1998].

RIBEIRO, Aquilino. Volfrâmio. Lisboa: Livraria Bertrand, 1961 [1943].

SCOTT, Walter. Waverley. London: The Penguin English Library, 1983 [1814].

TORGA, Miguel. Montanha. Coimbra, 1941. 